\title{
KOMPARASI AKURASI MODEL M-SCORE DAN Z-SCORE DALAM MENDETEKSI FRAUDULENT FINANCIAL REPORTING
}

\author{
Dian Islamiyati ${ }^{1}$, Djauhar Edi Purnomo ${ }^{2}$, \\ ${ }^{1}$ Magister Akuntansi, Universitas Muhammadiyah Surakarta \\ 2 Program Studi Akuntansi FEB UMPP \\ Korespondensi e-mail: dianislamiyati789@gmail.com
}

\begin{abstract}
Abstrak
Penelitian ini bertujuan untuk membuktikan secara empiris akurasi dua model Fraudulent Financial Reporting antara analisis M-Score dan Z-Score pada perusahaan Manufaktur yang Listing di Bursa Efek Indonesia Periode 2018-2019. Jenis penelitian ini ialah penelitian kuantitatif dan data yang digunakan ialah data sekunder. Populasi penelitian ini ialah seluruh perusahaan manufaktur yang terdaftar di Bursa Efek Indonesia (BEI) periode 2018-2019. Teknik pengambilan sampel dilakukan dengan teknik purposive sampling. Berdasarkan kriteria yang telah ditetapkan, diperoleh sampel sebanyak 53 perusahaan dengan tahun pengamatan 2 tahun. Jumlah data uang diteliti 106 laporan perusahaan. Hasil dari penelitian ini, berdasarkan perhitungan menggunakan M-Score terdapat 67 perusahaan tergolong manipulator. Sedangkan berdasarkan perhitungan menggunakan Z-Score terdapat 49 perusahaan tergolong fraud/kebangkrutan. Hasil perhitungan tingkat akurasi dan tipe error model M-Score dan Z-Sore yang telah dilakukan menunjukkan bahwa tingkat akurasi model mscore sebesar 37\% dengan tipe error sebesar $60 \%$ sedangkan tingkat akurasi model z-score sebesar $64 \%$ dengan tipe error 40\%. Namun menurut hasil uji beda $Z$ antara kedua model, angka tersebut tidak menjelaskan tingkat akurasi Z-Score lebih tinggi dari M-Scrore karena tidak terdapat perbedaan M-Score dan Z-Score pada pengujian fraudulent financial reporting.

Kata Kunci: Fraudulent Financial Reporting, Benish M-Score, Altman Z-Score
\end{abstract}

\section{ACCURACY OF M-SCORE AND Z-SCORE MODELS IN DETECTING FRAUDULENT FINANCIAL REPORTING}

\section{Abstrack}

This study aims to prove empirically the accuracy of the two Fraudulent Financial Reporting models between the M-Score and Z-Score analysis in manufacturing companies listing on the Indonesia Stock Exchange for the 2018-2019 period. This type of research is quantitative research and the data used is secondary data. The population of this study is all manufacturing companies listed on the Indonesia Stock Exchange (IDX) for the 2018-2019 period. The sampling technique was done by using purposive sampling technique. Based on the predetermined criteria, a sample of 49 companies was obtained with an observation of two years. The amaunt of financial report data studied was 106 financial reports. The results of this study, based on calculations using the M-Score, there are 67 companies classified as manipulators. Meanwhile, based on the calculation using the Z-Score, there are 14 companies classified as fraud / bankruptcy. The results of the accuracy rate of m-score model is $37 \%$ with an error type of $60 \%$, while the accuracy rate of $z$-score is $64 \%$ with an error typr of $40 \%$. However, according to the Z-different tset, this figure does not explain that the accuracy of the Z-Score is 
higher than the M-Score because there are no difference in the M-Score and the Z-Score in the fraudulent financial reporting test.

Keywords: Fraudulent Financial Reporting, Benish M-Score, Altman Z-Score

\section{PENDAHULUAN}

Berdasarkan the Association of Certified Fraud Examiners (ACFE), Fraud merupakan perbuatan melawan hukum yang dilakukan dengan sengaja untuk tujuan tertentu, seperti manipulasi atau memberikan laporan keliru kepada pihak lain. Aktivitas itu bisa dilakukan oleh oknuim dari dalam atau luar perusahaan. Tujuannya, untuk mendapatkan keuntungan pribadi atau kelompok yang merugikan pihak lain, baik secara langsung maupun tidak langsung. Hasil survei dan penelitian ACFE Global menunjukkan bahwa setiap tahun rerata 5 persen dari pendapatan organisasi menjadi korban fraud. Di dalam situs Badan Pengawasan Keuangan dan Pembangunan (BPKP), perusahaan swasta bahkan Badan Usaha Milik Negara (BUMN) tidak terlepas dari risiko fraud.

Oleh sebab itu, pendeteksian pada Fraudulent Financial Reporting sangatlah penting, agar pihak yang berkepentingan, dalam hal ini adalah investor memiliki tingkat kewaspadaan dan dapat mengambil keputusan yang tepat dalam melakukan investasi di suatu perusahaan. Dari berbagai cara untuk mendeteksi Fraudulent Financial Reporting, penggunaan metode analisis M-Score dan Z-Score sering digunakan.

Metode M-Score merupakan model pendeksian fraud yang ditemukan Profesor Messod Daniel Beneish dengan menggunakan 8 rasio keuangan untuk mendapatkan skor tertentu dalam rangka identifikasi kemungkinan terjadinya fraud pada perusahaan. Rumus dari metode Beneish M-Score Model adalah:

$$
\begin{aligned}
\mathrm{M}= & -4.840+0,920 \mathrm{DSRI}+\text { 0,528GMI + 0,0404AQI + 0,892SGI + 0,115DEPI } \\
& \text { 0,172SGAI + 4,679 TATA- 0,327XLVGI }
\end{aligned}
$$

Dimana:

○ DSRI = Days Sales in Receivables Index

○ GMI = Gross Margin Index

○ DEPI $=$ Depreciation Index

- SGI = Sales Growth Index

○ LVGI = Leverage Index

- TATA = Total Accruals to Total Assets

- AQI = Asset Quality Index

○ $\mathrm{SGAI}=$ Sales, General and Administrative Expenses Index 
Bila nilai M-Score > -2.22 menandakan bahwa ada indikasi terjadi financial fraud pada perusahaan tersebut. Beneish M-Model digunakan oleh Data Mining untuk mengukur perusahaan yang melakukan kecurangan.

Sedangkan metode Z-Score dikembangkan oleh Altman telah digunakan di berbagai industri untuk memprediksi kebangkrutan, dan para peneliti juga menggunakannya untuk mendeteksi fraudulent financial reporting. diukur dengan rumus sebagai berikut:

$\mathrm{Z}=1.2$ (working capital/total assets) +1.4 (retained earnings/total assets) + 3.3 (EBIT/Total Assets) + 0.06 (Market value of equity/ book value of total debt) +1.0 (sales/total assets)

Perusahaan yang memiliki nilai Z-Score $>2,99$ dinilai sebagai perusahaan yang sehat dan yang memiliki nilai antara 1,81 hingga 2,99 dinilai sebagai perusahan yang berada pada grey area, sedangkan yang memiliki nilai di bawah 1,81 dinilai sebagai perusahaan yang memiliki potensi kebangkrutan.

Para peneliti terdahulu telah melakukan penelelitian pengaruh kedua metode tersebut dalam medeteksi fraudulent financial reporting. Nguyen Huu Anh dan Nguyen Ha Linh (2016) menunjukkan bahwa model M-score juga telah membuktikan kekuatannya yang kuat dalam mendeteksi EM di negara Vietnam, dan memberikan alat yang andal bagi investor dalam mengambil keputusan dan memverifikasi keandalan informasi akuntansi dalam laporan keuangan. Ini juga membantu bank atau lembaga keuangan lainnya dalam melindungi diri mereka dari penipuan atau kasus peminjaman yang tidak tertagih. Sedangkan Ganga Bhavani dan Christian Tabi Amponsah (2017) menemukan bahwa skor-Z yang mengukur kemungkinan kebangkrutan efektif dalam mendeteksi FFR. Penelitian ini menemukan bahwa tidak seperti skorBeneish, skor-Z Altman sangat efektif dalam mengidentifikasi FFR.

Dari hasil uraian latar belakang dan riset gab diatas, maka penulis merumuskan masalah dalam penelitian ini antara lain: Pertama, Berapakah persentase yang terindikasi manipulator dan non manipulator dengan model M-Score pada perusahaan Manufaktur yang Listing di Bursa Efek Indonesia Periode 2018-2019?; Kedua, Berapakah persentase yang terindikasi manipulator dan non manipulator dengan model Z-Score pada perusahaan Manufaktur yang Listing di Bursa Efek Indonesia Periode 2018-2019?; Ketiga, Bagaimanakah akurasi dua model M-Score dan Z-Score dalam Mendeteksi Fraudulent Financial Reporting pada perusahaan Manufaktur yang Listing di Bursa Efek Indonesia Periode 2018-2019?

Adapun tujuan penulisan yang dicapai berdasarkan rumusan masalah di atas antara lain: Pertama, Untuk mengetahui dan menganalisis perhitungan presentase yang terindikasi manipulator dan non manipulator dengan model 
M-Score pada perusahaan Manufaktur yang Listing di Bursa Efek Indonesia Periode 2018-2019; Kedua, Untuk mengetahui dan menganalisis perhitungan presentase yang terindikasi manipulator dan non manipulator dengan model Z-Score pada perusahaan Manufaktur yang Listing di Bursa Efek Indonesia Periode 2018-2019; Ketiga, untuk membuktikan secara empiris akurasi dua model M-Score dan Z-Score dalam Mendeteksi Fraudulent Financial Reporting pada perusahaan Manufaktur yang Listing di Bursa Efek Indonesia Periode 2018-2019.

Melalui penelitian ini, diharapkan hasilnya dapat memberikan manfaat bagi semua pihak yang berkepentingan, yaitu: Bagi Akademik, diharapkan dapat menjadi hasil penelitian yang bermanfaat dalam mengimplementasikan pengetahuan penulis tentang konsentrasi ilmu akuntansi forensik yang telah diperoleh di bangku kuliah; Bagi Perusahaan, hasil penelitian ini dapat dijadikan acuan perusahaan dalam mendeteksi adanya praktek kecurangan, baik secara internal maupun eksternal, sehingga angka kecurangan dalam perusahaan dapat ditekan; Bagi Investor dan Kreditor, hasil penelitian ini diharapkan dapat memberikan pertimbangan dalam pengambilan keputusan investasi dan dapat memberikan informasi, manakah perusahaan Industri Perbankan yang Listing di Bursa Efek Indonesia Periode 2018-2019 yang tergolong manipulator dan manakah perusahaan yang tergolong non manipulator.

\section{Metode Penelitian \\ Jenis Penelitian}

Penelitian ini menggunakan pendekatan kuantitatif dimana data yang diambil berupa angka. Data dalam penelitian ini adalah data sekunder yang diambil dari laporan keuangan perusahaan manufaktur yang terdaftar di Bursa Efek Indonesia (BEI) tahun 2018 sampai dengan tahun 2019.

\section{Waktu dan Tempat Penelitian}

Waktu Penelitian ini dilakukan pada bulan Mei 2021 dan tempat penelitian dilakukan pada perusahaan manufaktur yang listing di Bursa Efek Indonesia dengan mengambil data yang diperlukan di website www.idx.co.id.

\section{Target/Subjek Penelitian}

Subjek dalam penelitian ini adalah seluruh perusahaan yang termasuk dalam kelompok perusahaan manufaktur yang terdaftar di Bursa Efek Indonesia (BEI) periode 2018-2019. Metode pemilihan sampel yang digunakan dalam penelitian ini adalah dengan menggunakan teknik purposive sampling.

\section{Prosedur}

Jenis data yang digunakan dalam penelitian ini adalah data sekunder, yang bersumber pada laporan tahunan (annual report) dan laporan keungan auditan perusahaan manufaktur tahun 2018 sampai dengan tahun 2019. Data sekunder yang digunakan dalam penelitian ini adalah laporan tahunan pada 
perusahaan manufaktur yang terdaftar di Bursa Efek Indonesia (BEI) tiga periode yaitu mulai dari tahun 2018 sampai dengan 2019 dengan mengunduh situs resmi Bursa Efek Indonesia (BEI) www.idx.co.id.

\section{Data, Instrumen, dan Teknik Pengumpulan Data}

Data penelitian ini menggunakan data sekunder yang diambil dari laporan keuangan perusahaan manufaktur yang terdaftar di Bursa Efek Indnesia dengan menggunakan teknik purposive sampling. Adapun kriteria yang digunakan saat pemilihan sampel yaitu diantaranya:

Tabel 1. Prosedur dan Hasil Pemilihan Sampel Perusahaan

\begin{tabular}{|l|c|}
\hline \multicolumn{1}{|c|}{ Kriteria } & Jumlah \\
\hline $\begin{array}{l}\text { Perusahaan manufatur yang sahamnya terdaftar di BEI selama periode } \\
\text { 2018-2019. }\end{array}$ & 183 \\
\hline $\begin{array}{l}\text { Data yang berkaitan dengan variabel penelitian disajikan secara lengkap } \\
\text { (data secara keseluruhan tersedia pada publikasi selama periode 2018- } \\
\text { 2019). }\end{array}$ & $(11)$ \\
\hline $\begin{array}{l}\text { Perusahaan yang tidak mengalamai peningkatan penjualan atau } \\
\text { revenue dari tahun 2018 ke tahun 2019 }\end{array}$ & $(65)$ \\
\hline $\begin{array}{l}\text { Perusahaan yang tidak mengalamai peningkatan laba dari tahun 2018 } \\
\text { ke tahun 2019 }\end{array}$ & $(48)$ \\
\hline $\begin{array}{l}\text { Perusahaan manufaktur yang menggunakan mata uang selain mata } \\
\text { uang Rupiah }\end{array}$ & $(6)$ \\
\hline Sampel perusahaan & $\mathbf{5 3}$ \\
\hline Sampel perusahaan selama dua tahun (53 x 2) & $\mathbf{1 0 6}$ \\
\hline Total Objek Pengamatan & $\mathbf{1 0 6}$ \\
\hline
\end{tabular}

Sumber: Data yang diolah

\section{Teknik Analisis Data}

Teknik analisis Ratio Index terhadap data laporan keuangan perusahaan yang menjadi sampel digunakan dalam analisis penelitian ini. Perhitungan ratio index ini bertujuan untuk menentukan kategori suatu perusahaan yang tergolong perusahaan manipulator atau perusahaan non manipulator. Perusahaan dapat dikategorikan sebagai perusahaan manipulator atau perusahaan non manipulator apabila mendapatkan nilai ratio index sesuai dengan indeks parameter menurut Beneish Model dan Altman Z Score. Langkahlangkah yang digunakan untuk perhitungan ratio index untuk menentukan kategori perusahaan tergolong manipulator atau non manipulator adalah sebagai berikut:

1. Menghitung Ratio Index Perusahaan/ Indeks Hitung Beneish M- Score.

Menurut Beneish (1999) kita harus menghitung ratio index perusahaan dengan beberapa variabel sebelum menentukan kriteria penggolongan perusahaan, variable-variabel tersebut antara lain:

a.Days Sales in Receivables Index (DSRI) 
DSRI $=\frac{\text { Receivables Current year / sales current }}{\text { year Receivables prior year / sales prior year }}$

Keterangan:

- Account Receivable = Piutang Dagang

- Sales = Penjualan

- $\mathrm{t}=$ periode $\mathrm{t}$

- $\mathrm{t}-1$ = periode $\mathrm{t}-1$

b. Gross Margin Index (GMI)

GMI

$=\frac{(\text { Sales prior year }- \text { COGS prior year }) / \text { sales prior year }}{\text { (Sales current year -COGS current year) / sales current year }}$

Keterangan:
- Sales
$=$ Penjualan
- Cost of Good Sold = Harga Pokok Penjualan
○ $\mathrm{t}$
$=$ periode $\mathrm{t}$
○ $\mathrm{t}-1$
$=$ periode $t-1$

c. Asset Quality Index (AQI)

$\mathrm{AQI}=\frac{(1-\text { Current aset prior year }+ \text { net fixed aset prior year }) / \text { Total aset prior year }}{(1-\text { Current aset current year }+ \text { net fixed aset current year }) / \text { Total aset current year }}$

Keterangan:

- Current Assets = Aktiva Lancar

- Net Fixed Asset = Aktiva Tetap

- Total Assets = Total Aktiva

$0 \mathrm{t}=$ periode $\mathrm{t}$

$\circ \mathrm{t}-1=$ periode $\mathrm{t}-1$

d. Sales Growth Index (SGI)

$S G I$

Keterangan:

○ Sales= Penjualan

e. Depreciation Index (DEPI) 


\section{DEPI}

$$
=\frac{\text { Depreciation } /(\text { Depreciation }+P P E) \text { prior year }}{\text { Depreciation } /(\text { Depreciation }+P P E) \text { current year }}
$$

Keterangan:

- Depreciation= Depresiasi

○ PPE (Plant, Property,Equipment) = Aktiva Tetap

f. Sales General and Administrative Expenses Index (SGAI)

$$
\mathrm{SGAI}=\frac{(\text { SGA Expense / sales }) \text { current year }}{(\text { SGA Expense / sales }) \text { prior year }}
$$

Keterangan:

$\begin{array}{lll}\circ & \text { SGA } \quad=(\text { Sales General and Administrative }) \\ \circ & \text { Expense } \quad \text { Biaya penjualan } \\ \circ & \text { Administrasi Sales }=\text { Penjualan }\end{array}$

g. Leverage Index (LVGI)

LVGI $=\frac{((\text { Long Term Debt }+ \text { Current Liabilities }) / \text { Total Aset Prior Year })}{((\text { Long Term Debt }+ \text { Current Liabilities }) / \text { Total Aset Current Year })}$

Keterangan:
○ Long Term Debt = Hutang Jangka Panjang
- Current Liabilities $=$ Hutang Lancar
- Total Assets = Total Aktiva

h. Total Accruals to Total Assets (TATA)

TATA $=\frac{\Delta \text { Working Capital }-\Delta \text { Cash }-\Delta \text { Current Taxes Payable }- \text { Depreciation and Amortization }}{\text { Total Asset }}$

Working Capital $=$ Current Assets - Current Liabilities

Keterangan:

- $\Delta$ Working Capital $=$ Perubahan Modal Kerja 


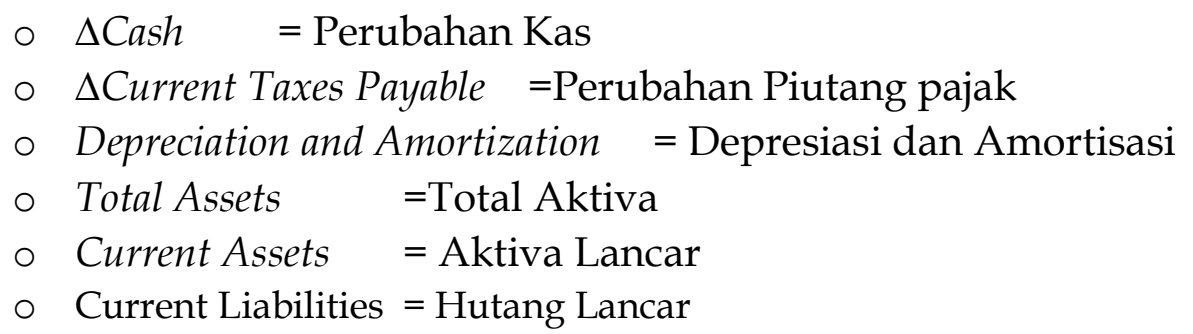

2. Analisis Fraudelent dengan formula Beneish M Score

Setelah kedelapan rasio tersebut dilakukan perhitungan, maka hasil perhitungan diformulasikan kedalam rumus Beneish $M$ Score model :

Beneish M Score : $-4,84+0,920$ DSRI + 0,528 GMI + 0,404 AQI + 0,892 SGI + 0,115 DEPI - 0,172 SGAI - 0,392 LVGI + 4,697 TATA

Jika nilai Beneish $M$ Score lebih besar dari -2,22, maka dapat disimpulkan bahwa perusahaan tersebut digolongkan sebagai perusahaan manipulator, dan jika nilai Beneish $M$ Score kurang dari -2,22 maka dapat disimpulkan bahwa perusahaan digolongkan sebagai perusahaan non manipulator. (Fabelli, 2011).

3. Menghitung index hitung ratio Altman Z-Score

$$
\begin{aligned}
& \text { T1: WCTA } \\
& =\frac{\text { Working Capital }}{\text { Total Asset }} \\
& \text { T2: RETA } \\
& =\frac{\text { Retained Earning }}{\text { Total Asset }} \\
& \text { T3: EBITTA } \\
& =\frac{\text { EBIT }}{\text { Total Asset }} \\
& \text { T4: MVEBVL } \\
& =\frac{\text { Market Value of equity }}{\text { Total liability }}
\end{aligned}
$$

T5: STA

4. Analisis Fraudulent dengan Altman Z Score

Formula untuk perusahaan manufaktur adalah :

Z-Score $=0.717 \mathrm{~T} 1+0.847 \mathrm{~T} 2+3.107 \mathrm{~T} 3+0.420 \mathrm{~T} 4+0.998 \mathrm{~T} 5$

Kriteria Penggolongan:

- Z-Score > 2,60 - Berdasarkan laporan keuangan, perusahaan dianggap aman

- 1,1 $\leq$ Z-Score $<2,60$ - Terdapat kondisi keuangan di suatu bagian yang membutuhkan perhatian khusus

- $\quad \mathbf{Z}<\mathbf{1 , 1}$ - Perusahaan berpotensi kuat akan mengalami kebangkrutan/fraud 
5. Menghitung Tingkat Akurasi Hasil Prediksi

Pada tahap ini, akan dilakukan penghitungan tingkat akurasi pada model M-Score dan Altman Z-Score untuk menilai model manakah yang merupakan prediktor paling baik diantara kedua model dalam mendeteksi fraudulent financial reporting. Pada seluruh sampel yang ada, akan dilakukan perbandingan antara prediksi dan kategori sampel. Setelah semua sampel selesai dihitung, maka akan diperoleh hasil rekap prediksi yang benar dan yang salah. Dari rekap prediksi tersebut dapat diketahui tingkat akurasi setiap model yang digunakan. Berapa persen model tersebut dapat memprediksi dengan benar dari keseluruhan perusahaan yang ada dapat diketahui dari perhitungan tingkat akurasi. Tingkat akurasi tiap metode dihitung dengan cara sebagai berikut :

$$
\text { Tingkat Akurasi }=\frac{\text { Jumlah benar }}{\text { Jumlah Sampel }} \times 100 \%
$$

Jumlah prediksi benar adalah jumlah sampel perusahaan Manufaktur yang dinyatakan tidak mengalami Fraudulent Financial Reporting oleh Bursa Efek Indonesia dan hasil perhitungan model M-Score dan Z-Score juga dinyatakan tidak mengalami Fraudulent Financial Reporting. Jumlah sampel adalah jumlah perusahaan yang dijadikan sampel pada penelitian ini.

Setelah dilakukan perhitungan tingkat akurasi setiap model, dalam model ini juga dilakukan perhitungan tingkat error setiap model. Tingkat error adalah tingkat kesalahan yang terjadi jika hasil prediksi menggunakan model M-Score dan Z-Score menyatakan perusahaan (sampel) mengalami Fraudulent Financial Reporting. Tingkat error dihitung dengan cara sebagai berikut:

$$
\text { Tingkat Error }=\frac{\text { Jumlah Kesalahan }}{\text { Jumlah Sampel }} \times 100 \%
$$

Jumlah kesalahan menunjukkan jumlah sampel perusahaan manufaktur yang dinyatakan oleh tidak mengalami Fraudulent Financial Reporting Bursa Efek Indonesia (BEI) akan tetapi hasil analisis model M-Score dan Z-Score menyatakan bahwa perusahaan tersebut mengalami Fraudulent Financial Reporting. Jumlah sampel menunjukkan jumlah perusahaan yang dijadikan sampel pada penelitian ini yaitu perusahaan manufaktur yang terdaftar di Bursa Efek Indonesiapada periode 2018-2019.

6. Menghitung Uji Beda antara Kedua Model

Uji beda variable yang digunakan dalam pengujian ini adalah uji Z: Perbedaan dua rata-rata. Uji-Z disini mengacu pada analisis statistic univariat yang digunakan untuk menguji hipotesis bahwa proporsi kedua sampel independent tersebut sangat berbeda. Hal ini menentukan sejauh mana suati titik data jauh dari rata-rata set data, dalam standar deviasi. 
Penulis menggunakan pengujian ini karena varians populasi diketahui, ukuran sampel dalam jumlah besar dan varians sampel dianggap sama dengan varians poulasi.

Asumsi uji-Z:

- Semua pengamatan sampel independent

- Jumlah sampel harus lebih dari 30

- Distribusi Z adalah normal dan mean nol.

Dari sampel rondom yang diambil kemudian dihitung nilai $Z$, dengan rumus:

$$
Z=\frac{\bar{x}-\mu}{\sigma / \sqrt{n}}
$$

Dimana :

$\mu$ : sebuah harha yang diketahui dan titentukan oleh peneliti

Z: harga pada distribusi normal baku

Kesimpulan dari perhitungan dapat ditarik apabila memenuhi kriteria jika nilai signifikansi sig. (2-tiled) $<0,05$ terdapat pebedaan antara kedua model, dan berlau sebaliknya.

\section{Hasil dan Pembahasan}

1. Penggolongan Analisis M-Score

Tabel 2. Hasil Perhitungan Presentase Golongan M-Score

\begin{tabular}{|c|c|c|c|c|c|}
\hline \multirow{2}{*}{ No } & \multirow{2}{*}{ Golongan } & \multicolumn{2}{|c|}{2018} & \multicolumn{2}{c|}{2019} \\
\cline { 3 - 6 } & & Jumlah & Presentase & Jumlah & Presentase \\
\hline 1 & Manipulator & 33 & $62 \%$ & 34 & $64 \%$ \\
\hline 2 & Non Manipulator & 20 & $38 \%$ & 19 & $36 \%$ \\
\hline
\end{tabular}

Sumber: Data diolah

Manurut hasil analisis M-Score yang telah dilakukan, pada tahun 2018 terdapat 20 perusahaan atau $38 \%$ dari total sampel perusahaan yang tergolong non-manipulator dan 33 Perusahaan atau 62\% dari total sampel perusahaan yang tergolong manipulator. Sedangkan pada tahun 2019 terdapat 19 perusahaan atau $36 \%$ dari total sampel perusahaan yang tergolong non manipulator dan 34 perusahaan atau $64 \%$ dari total sampel perusahaan tergolong manipulator. Hal tersebut menunjukkan bahwa dominan perusahaan sampel tergolong dalam perusahaan manipulator. Hal ini dapat disebabkan karena dominan perusahaan sampel melakukan earning manajemen pada saat menyusun laporan keuangan mereka agar mendapatkan harga saham setinggi-tingginya. Hal tersebut sejalan dengan penelitian Nguyen Huu Anh dan Nguyen Ha Linh (2016) meneliti tentang "Using the M-score Model in Detecting Earnings Management: Evidence from Non-Financial Vietnamese Listed Companies". Hasil penelitian menunjukkan bahwa $48,4 \%$ perusahaan non-finansial Vietnam yang terdaftar di HOSE 
terlibat dalam manajemen laba dan pengamatan sampel sesuai dengan model Beneish M-score.

Hal serupa juga sejalan dengan hasil penelitian Hariri, et al. (2017) yang meneliti tentang "Predicting Financial Statements Corporate Fraud: Beneish MScore Model". Hasil menunjukkan bahwa Laporan keuangan pada periode 2010-2013 secara keseluruhan bahwa Beniesh M-Score XYZ, PT mencapai 3,94 pada 2010, 0,70 pada 2011, -3,32 pada 2012 dan -2,38 pada 2013, keseluruhan Beniesh M-Score mencapai di atas $-2,22$ kecuali pada tahun 2011. Model M-Score Beniesh menunjukkan bahwa manajemen telah melakukan praktik memanipulasi angka-angka pada laporan keuangan yang dilakukan secara terus menerus pada periode 2010, 2012 dan 2013.

2. Penggolongan Analisis Z-Score

Tabel 3

Hasil Perhitungan Presentase Golongan Z-Score

\begin{tabular}{|c|c|c|c|c|c|}
\hline \multirow{2}{*}{ No } & \multirow{2}{*}{ Golongan } & \multicolumn{2}{|c|}{2018} & \multicolumn{2}{|c|}{2019} \\
\cline { 3 - 6 } & Jumlah & Presentase & Jumlah & Presentase \\
\hline 1 & Aman & 28 & $53 \%$ & 29 & $55 \%$ \\
\hline 2 & $\begin{array}{c}\text { Perhatian } \\
\text { Khusus }\end{array}$ & 19 & $36 \%$ & 16 & $30 \%$ \\
\hline 3 & $\begin{array}{c}\text { Potensi } \\
\text { Bangkrut }\end{array}$ & 6 & $11 \%$ & 8 & $15 \%$ \\
\hline
\end{tabular}

Sumber: Data diolah

Manurut hasil analisis Z-Score yang telah dilakukan, menunjukkan pada tahun 2018 terdapat 28 perusahaan atau 53\% dari sampel perusahaan tergolong ke dalam kategori aman, 19 perusahaan atau 36\% dari rotal sampel perusahaan tergolong kedalam kategori persahaan dalam perhatian khusus, dan 6 perusahaan atau 11\% dari sampel perusahaan tergolong kedalam krategori perusahaan yang mengalami potensi bangkrut atau fraud. Pada tahun 2019 terdapat 29 perusahaan atau 55\% dari sampel perusahaan tergolong ke dalam kategori aman, 16 perusahaan atau 30\% dari rotal sampel perusahaan tergolong kedalam kategori persahaan dalam perhatian khusus, dan 8 perusahaan atau 15\% dari sampel perusahaan tergolong kedalam krategori perusahaan yang mengalami potensi bangkrut atau fraud. Metode Z-Score dikembangkan oleh Altman telah digunakan di berbagai industri untuk memprediksi kebangkrutan, dan para peneliti juga menggunakannya untuk mendeteksi fraudulent financial reporting. Salah satunya adalah Ganga Bhavani dan Christian Tabi Amponsah (2017). Hasil penelitian ini menunjukkan bahwa metode Z-Score dapat digunakan untuk mendeteksi fraud pada Toshiba Corporation. Menurutnya, bahwa skor Z yang mengukur probabilitas kebangkrutan juga efektif dalam memprediksi fraud.

Masoud Taherinia dan Reza Talebi (2019) juga mengatakan hal serupa, hasil penelitian mereka menunjukkan bahwa model Z-Score dapat 
memprediksi kecurangan dala laporan keuangan perusahaan yang aktif pada industri bahan dan produk farmasi serta industry otomotif pada perusahaan yab ng diterima di Bursa Efek Teheran. model Z-Score merupakan alat yang baik untuk mengevaluasi kemungkinan pelaporan yang curang di Iran.

3. Perhitungan Tingkat Akurasi Hasil Prediksi dan Tipe Error

a. Tingkat akurasi dan Tipe Error model M-Score

Tabel 4

Hasil Perhitungan Tingkat Akurasi Model M-Score

\begin{tabular}{|c|c|c|}
\hline Prediksi Benar & Sampel & Tingkat Akurasi \\
\hline 39 & 106 & $37 \%$ \\
\hline
\end{tabular}

Sumber: Data diolah

Sedangkan tipe error untuk model M-Score dapat dilihat pada table berikut:

Tabel 5

Hasil Perhitungan Tipe Error Model M-Score

\begin{tabular}{|c|c|c|}
\hline Prediksi Salah & Sampel & Tipe Error \\
\hline 64 & 106 & $60 \%$ \\
\hline
\end{tabular}

Sumber: Data diolah

b. Tingkat Akurasi dan Tipe model Z-Score

Hasil pengujian tingkat akurasi model M-Score dapat dilihat pada table berikut:

Tabel 6

Hasil Perhitungan Tingkat Akurasi Model Z-Score

\begin{tabular}{|c|c|c|}
\hline Prediksi Benar & Sampel & Tingkat Akurasi \\
\hline 57 & 106 & $54 \%$ \\
\hline
\end{tabular}

Sumber: Data diolah

Sedangkan tipe error untuk model M-Score dapat dilihat pada table berikut:

Tabel 7

Hasil Perhitungan Tipe Error Model Z-Score

\begin{tabular}{|c|c|c|}
\hline Prediksi Salah & Sampel & Tipe Error \\
\hline 43 & 106 & $40 \%$ \\
\hline
\end{tabular}

Sumber: Data diolah

Hasil perhitungan tingkat akurasi dan tipe error model M-Score dan ZSore yang telah dilakukan menunjukkan bahwa tingkat akurasi model mscore sebesar $37 \%$ dengan tipe error sebesar $60 \%$ sedangkan tingkat 
akurasi model z-score sebesar $64 \%$ dengan tipe error $40 \%$. Hal ini menunjukkan bahwa tingkat akurasi model z-score lebih tinggi dari model m-score. Hal ini sejalan dengan penelitian Tanusdjaja Hendang dan Kurniawan Fanny Magdalena (2018) yang membuktikan bahwa Hasil menunjukkan bahwa Metode Altman Z Score - Financial Ratio lebih berpengaruh dalam mendeteksi fraudulent financial reporting daripada metode Beneish M-Score Model.

Hasil penelitian Ofori Edmond (2016) menunjukkan bahwa Kedua model yang digunakan untuk menganalisis data yang diambil dari laporan 10K tahunan Enron Company memiliki kekurangan masing-masing. Kedua model menderita dari efek definisi metrik yang digunakan dalam melakukan analisis keuangan. Oleh karena itu, kedua model ini dapat menghasilkan nilai yang berbeda untuk beberapa metrik yang digunakan untuk menghitung rasio. Ini dapat menghasilkan berbagai prediksi risiko default perusahaan dan manipulasi pendapatan.

Hasil penelitian Islam Muhammad (2019) menunjukkan bahwa Berdasarkan perhitungan menggunakan beneish ratio index terdapat 50 perusahaan tergolong manipulator. Sedangkan berdasarkan perhitungan menggunakan altman $\mathrm{z}$ score terdapat 28 perusahaan tergolong fraud/kebangkrutan Hasilnya dari tahun 2016 sampai dengan tanggal 26 Juni 2019 tidak ditemukan perusahaan manufaktur yang dikenai sanksi Otoritas Jasa Keuangan terkait kecurangan laporan keungan. Namun, bedasarkan berita online terkait dengan adanya indikasi kecurangan laporan keuangan ditemukan 3 perusahaan yaitu PT Tiga Pilar Sejahtera Food Tbk, PT Krakatau Steel (Persero) Tbk dan PT Bentoel Internasional Investama Tbk. Almant z score lebih mampu mendeteksi indikasi kecurangan atas ketiga perusahaan tersebut dibandingkan dengan beneish ratio index.

Tabel 8. Perusahaan yang Terkonfirmasi Mengalami Fraud

\begin{tabular}{|c|c|c|}
\hline No & Perusahaan & Indikasi (Sumber) \\
\hline 1 & $\begin{array}{l}\text { AISA (Tiga Pilar Sejahtera } \\
\text { Food Tbk) }\end{array}$ & $\begin{array}{l}\text { O Pada tahun } 2019 \text { melakukan penggelapan } \\
\text { dana deposito Taro swnilai } 20 \text { miliar di BNI } \\
\text { Syariah (Kontan.co.id) } \\
\text { BEI memanggil manajemen AISA terkait } \\
\text { penggelembungan laporan keuangan senilai } \\
\text { Rp } 4 \text { triliun yang diperoleh dari hasil } \\
\text { investigasi PT Ernst \& Young Indonesia } \\
\text { (medcom.id) }\end{array}$ \\
\hline 2 & BELL & $\begin{array}{l}\text { PT Trisula Textile Industries Tbk hingga } \\
\text { kuartal III-2020 mencatat penjualan sebesar Rp } \\
\text { 433,25 Miliar. Angka ini sedikut terkoreksi } \\
\text { 3,9\% YoY dibandingkan periode yang sama } \\
\text { tahun sebelumnya. }\end{array}$ \\
\hline
\end{tabular}




\begin{tabular}{|c|c|c|c|}
\hline & & & (sinarmassekuritas.co.id) \\
\hline 3 & $\begin{array}{l}\text { RMBA } \\
\text { Internasional } \\
\text { Tbk) }\end{array}$ & $\begin{array}{r}\text { (Bentoel } \\
\text { Investama }\end{array}$ & $\begin{array}{l}\text { Lembaga tax justice network pada tanggal } 8 \\
\text { mei } 2019 \text { melaporkan bahwa perusahaan } \\
\text { tembakau milik british American tobacco } \\
\text { (BAT) telah melakukan penghindaran pajak } \\
\text { melalui PT Bantoel Internasional Investama } \\
\text { Tbk. Sebagai dampaknya negara bisa merugi } \\
\text { US\$ } 14 \text { juta pertahun. (kontan.co.id) }\end{array}$ \\
\hline
\end{tabular}

4. Analisis Uji Beda Kedua Model

Uji beda variable yang digunakan dalam pengujian ini adalah uji Z: Perbedaan dua rata-rata. Uji-Z mengacu pada analisis statistic univariat yang digunakan untuk menguji hipotesis bahwa proporsi dua sampel independent sangat berbeda. Hal ini menentukan sejauh mana suati titik data jauh dari rata-rata set data, dalam standar deviasi.

Tabel 9. Z-Test: Two Sample for Means

\begin{tabular}{lrr}
\hline & Variable & Variable \\
& \multicolumn{1}{c}{1} & \multicolumn{1}{c}{2} \\
\hline Mean & $-0,07392$ & 6,384691 \\
Known Variance & 197,1 & 142,65 \\
Observations & 106 & 106 \\
Hypothesized Mean & \multicolumn{2}{|}{} \\
Difference & 0 & \\
$Z$ & $-3,60755$ & \\
$\mathrm{P}(\mathrm{Z}<=\mathrm{z})$ one-tail & 0,000155 & \\
z Critical one-tail & 1,644854 & \\
$\mathrm{P}(\mathrm{Z}<=\mathrm{z})$ two-tail & 0,000309 & \\
z Critical two-tail & 1,959964 & \\
\hline
\end{tabular}

Sumber: Data diolah

Pada table diatas dapat dilihat $Z_{\text {hitung }}$ sebesar $-3,60755$ sedangkan nilai $Z_{\text {tabel }}$ pada taraf signifikansi 0,05 dengan nilai sebesar 0,0001. Hal ini berarti $Z_{\text {hitung }}<Z_{\text {tabel }}$ yaitu $-3,60755<0,0001$ maka $\mathrm{H}_{\mathrm{O}}$ diterima dan $\mathrm{H}_{\mathrm{a}}$ ditolak. Artinya tidak terdapat perbedaan M-Score dan Z-Score pada pengujian fraudulent financial reporting.

\section{SIMPULAN DAN SARAN}

\section{Simpulan}

Tujuan dari penelitian ini adalah untuk mendeteksi Fraudulent Financial Reporting pada perusahaan Manufaktur yang Listing di Bursa Efek Indonesia 
Periode 2018-2019 dengan analisis M-Score dan Z-Score. Hasil penelitian ini menunjukkan bahwa kedua model tersebut dapat digunakan untuk mendeteksi fraud.

Manurut hasil analisis M-Score yang telah dilakukan, pada tahun 2018 terdapat 20 perusahaan atau $38 \%$ dari total sampel perusahaan yang tergolong non-manipulator dan 33 Perusahaan atau 62\% dari total sampel perusahaan yang tergolong manipulator. Sedangkan pada tahun 2019 terdapat 19 perusahaan atau 36\% dari total sampel perusahaan yang tergolong non manipulator dan 34 perusahaan atau 64\% dari total sampel perusahaan tergolong manipulator. Hal ini dapat disebabkan karena dominan perusahaan sampel melakukan earning manajemen pada saat menyusun laporan keuangan mereka agar mendapatkan harga saham setinggi-tingginya.

Manurut hasil analisis Z-Score yang telah dilakukan, menunjukkan pada tahun 2018 terdapat 28 perusahaan atau 53\% dari sampel perusahaan tergolong ke dalam kategori aman, 19 perusahaan atau 36\% dari rotal sampel perusahaan tergolong kedalam kategori persahaan dalam perhatian khusus, dan 6 perusahaan atau $11 \%$ dari sampel perusahaan tergolong kedalam krategori perusahaan yang mengalami potensi bangkrut atau fraud. Pada tahun 2019 terdapat 29 perusahaan atau 55\% dari sampel perusahaan tergolong ke dalam kategori aman, 16 perusahaan atau 30\% dari rotal sampel perusahaan tergolong kedalam kategori persahaan dalam perhatian khusus, dan 8 perusahaan atau $15 \%$ dari sampel perusahaan tergolong kedalam krategori perusahaan yang mengalami potensi bangkrut atau fraud. Metode Z-Score dikembangkan oleh Altman telah digunakan di berbagai industri untuk memprediksi kebangkrutan, dan para peneliti juga menggunakannya untuk mendeteksi fraudulent financial reporting.

Hasil perhitungan tingkat akurasi dan tipe error model M-Score dan ZSore yang telah dilakukan menunjukkan bahwa tingkat akurasi model m-score sebesar 37\% dengan tipe error sebesar $60 \%$ sedangkan tingkat akurasi model zscore sebesar $64 \%$ dengan tipe error $40 \%$. Namun menurut hasil uji beda Z antara kedua model, angka tersebut tidak menjelaskan tingkat akurasi Z-Score lebih tinggi dari M-Scrore karena tidak terdapat perbedaan M-Score dan Z-Score pada pengujian fraudulent financial reporting.

\section{Saran}

Untuk penelitian selanjutnya agar menambahkan alat deteksi kecurangan laporan keuangan dan sampel yang lebih luas. Hal ini dikarenakan dalam siaran pers Otoritas Jasa Keuangan banyak kasus yang menjerat sektor tersebut. Selain itu, hasil dari penelitian ini dapat dijadikan acuan apabila pada tahun 
yang akan datang perusahaan yang terindikasi melakukan manipulator dan fraud/kebangkrutan terbukti dikenakan sanksi oleh Otoritas Jasa Keuangan.

\section{REFERENSI}

Anh, Nguyen Huu dan Nguyen Ha Linh. 2016. "Using the M-score Model in Detecting Earnings Management: Evidence from Non-Financial Vietnamese Listed Companies". Hanoi: VNU Journal of Science: Economics and Business, Vol.32, No. 2 (2016) 14-23.

Bhavani, Ganga dan Christian Tabi Amponsah. 2017. "M-Score And Z-Score For Detection of Accounting Fraud". Dubai: Accountancy Business and the Public Interest 2017.

Dalnial, Hawariah et al. 2014. "Accountability in financial reporting: detecting fraudulent firms". Selangor: 1877-0428 (C) 2014 Elsevier Ltd.

Dwijayani, Septia, et al. 2019. “ANALISIS FRAUD TRIANGLE UNTUK MENDETEKSI KECURANGAN LAPORAN KEUANGAN (Studi Empiris Pada Perusahaan Manufaktur Yang Terdaftar di BEI Periode 2014-2017). Padang: Jurnal Eksplorasi Akuntansi Vol. 1, No 1, Seri D, Februari 2019, Hal 445-458 ISSN: 2656-3649 (Online) http://jea.ppj.unp.ac.id/index.php/jea/issue/view/4

Hariri, et al. 2017. "Predicting Financial Statements Corporate Fraud: Beneish MScore Model". Malang: Jurnal Ilmiah Bidang Akuntansi dan Manajemen (JEMA) Vol. 14 No. 2 (2017) http:/ / riset.unisma.ac.id/index.php/jema

Hendang Tanusdjaja dan Fanny Magdalena Kurniawan. 2018. "Analisis Komparasi Metode Altman Z-Score - Financial Ratio Dan Metode Beneish M-Score Model - Data Mining Dalam Mendeteksi Fraudulent Financial Reporting". Jakarta: Jurnal Muara Ilmu Ekonomi dan Bisnis Vol. 2, No. 1, April 2018: hlm 14-28 ISSN 2579-6224 (Versi Cetak) ISSN-L 2579-6232 (Versi Elektronik).

Islam, Mohammad. 2019. “Komparasi Akurasi Dua Model Kecurangan Laporan Keuangan Menggunakan Beneish Ratio Index Dan Altman Z Score Pada Perusahan Manufaktur Tbk 2016-2017". Jurnal Seminar Nasional Cendekiawan ke 5 Tahun 2019 ISSN (P) : 2460 - 8696 Buku 2: "Sosial dan Humaniora" ISSN (E) : 2540 - 7589

Kartikasari, Rima Novi dan Gugus Irianto. 2010. "Penerapan Model Beneish (1999) Dan Model Altman (2000) Dalam Pendeteksian Kecurangan Laporan Keuangan". Malang: Jurnal Akuntansi Multiparadigma, Vol. 1 No. 2 Agustus 2010.

Koshti, Jayashree R. 2019. "An Application of Altman Z-Score and Beneish M-Score Model on Selected Textiles Companies". India: IJESC Volume 9 Issue No.11 ISSN 23213361 ( 2019

Lotfi, Nasrin dan Arezoo Aghaei Chadegani. 2017. "Detecting Corporate Financial Fraud using Beneish M-Score Model". Najafabad: International Journal of Finance and Managerial Accounting, Vol.2, No.8, Winter 2017. 
Mavengere, Kudakwashe. 2015. "Predicting corporate bankruptcy and earnings manipulation using the Altman Z-score and Beneish $M$ score. The case of $Z$ manufacturing firm in Zimbabwe." International Journal of Management Sciences and Business Research, Oct -2015 ISSN (2226-8235) Vol-4, Issue 10 http:/ / www.ijmsbr.com Page 8.

Mehta, Anupam dan Ganga Bhavani. 2017. "Application of Forensic Tools to Detect Fraud: The Case of Toshiba". Dubai: Journal of Forensic and Investigative Accounting Volume 9: Issue 1, January-June, 2017.

Nugroho, Albert Adi et al. 2018. "Pengaruh Profitabilitas, Likuiditas, Leverage, dan Corporate Governance Terhadap Kecurangan Laporan Keuangan, Serta Financial Distresssebagai Variabel Intervening." Malang: Media Trend Berkala Kajian Ekonomi dan Studi Pembangunan MediaTrend 13 (2) 2018 p. 219-240 http://journal.trunojoyo.ac.id/mediatrend

Ofori, Edmond. 2016. "Detecting Corporate Financial Fraud Using Modified Altman Z-Score and Beneish M-Score. The Case of Enron Corp". Ghana: Research Journal of Finance and Accounting ISSN 2222-1697 (Paper) ISSN 22222847 (Online) Vol.7, No.4, 2016.

Pribadi, Alfian Ronggo et al. 2018. "Rasio-Rasio Keuangan Dalam Memprediksi Kecurangan". Bengkulu: ULTIMA Accounting | ISSN 2085-4595

Sabrina, Oriza Zea, et al. 2020. "Pengaruh koneksitas organ corporate governance, ineffective monitoring dan manajemen laba terhadap fraudulent financial reporting (The effect of corporate governance, ineffective monitoring and earnings management concept on fraudulent financial reporting)". Padang: Jurnal Akuntansi Keuangan dan Manajemen (Jakman) ISSN: 27160807, Vol 1, No 2, 2020, 109-122 https:// doi.org/10.35912/jakman.v1i2.11

Samsulubis, Sulton et al. "The Effect Of Profitability And Liquidity On Frances Of Financial Reports (Fraud), And Education Of Financial Distress (Empirical Study on Hotels, Restaurants and Tourism Sub Sector Companies Registered at IDX 2013-2017Period)". Semarang

Santosa, Setyarini dan Josep Ginting. 2019. "Evaluasi Keakuratan Model Beneish M-Score Sebagai Alat Deteksi Kecurangan Laporan Keuangan (Kasus Perusahaan Pada Otoritas Jasa Keuangan di Indonesia)" Majalah Ilmiah Bijak Vol. 16, No. 2, September 2019, pp. 75-84 75 E ISSN 2621-749X http://ojs.stiami.ac.id

bijakjournal@gmail.com/jurnal.bijak@stiami.ac.id

Taherinia, Masoud dan Reza Talebi. 2019. "Ability Of Fraud Triangle, Fraud Diamond, Beneish M Score, And Altman Z Score To Predict Financial Statements Fraud". Iran: Journal of Economic and Social Research ISSN: 1302-1060.

Talab, Hassnain Raghib et al. 2017. "Role of Beneish M-score Model in Detecting of Earnings Management Practices: Empirical Study in Listed Banks of Iraqi Stock Exchange". Iraq: International Journal of Applied Business and Economic Research ISSN: 0972-7302 available at http: 
www.serialsjournals.com, Serials Publications Pvt. Ltd.Volume 15 Number 23 (Part 2) • 2017.

Widodo, Arief dan Muchamad Syafruddin. 2017. "Pengaruh Pengungkapan Struktur Corporate Governance Terhadap Kecurangan Pelaporan Keuangan". Semarang: DIPONEGORO JOURNAL OF ACCOUNTING Volume 6, Nomor 4, Tahun 2017, Halaman 1-10 http://ejournals1.undip.ac.id/index.php/accounting ISSN (Online): 2337-3806.

Yanuary Eka Christy dan Daniel Sugama Stephanus. 2018. "Pendeteksian Kecurangan Laporan Keuangan dengan Beneish M-Score pada Perusahaan Perbankan Terbuka". Jurnal Akuntansi Bisnis, Vol. 16, No. 1, Maret 2018 ISSN 1412-775X (media cetak) | 2541-5204 (media online)

Zaki, Noha Mohamed. 2017. "The Appropriateness Of Fraud Triangle And Diamond Models In Assessing The Likelihood Of Fraudulent Financial Statements- An Empirical Study On Firms Listed In The Egyptian Stock Exchange." Egypt: International Journal of Social Science and Economic Research ISSN: 2455-8834 Volume:02, Issue:02.

Meliana, Trie Rundi Hartono. 2019. FRAUD PERBANKAN INDONESIA: STUDI EKSPLORASI Prosiding Seminar Nasional Pakar ke 2 Tahun 2019 ISSN (P) : 2615 - 2584 Buku 2: Sosial dan Humaniora ISSN (E) : $2615-3343$

Septian Deny. 2019. Tingkat Kecurangan Sektor Keuangan Indonesia Duduki Peringkat 2 di ASEAN. https://www.liputan6.com/bisnis/read/4083650/tingkatkecurangan-sektor-keuangan-indonesia-duduki-peringkat-2-di-asean\#. Diakses pada tanggal 1 Mei 2020

Wiji Nurhayat. 2019. kenali-fraud-laporan-keuangan-dan-praktik-yangmerugikan-perusahaan. https://www.jurnal.id/id/blog/kenali-fraudlaporan-keuangan-dan-praktik-yang-merugikan-perusahaan/. Diakses pada tanggal 1 Mei 2020 